\title{
NAŠE PANÍ DOKTORKA JARMILA EMMEROVÁ
}

\author{
PhDr. MARTIN MACHOVEC, \\ EDITOR, VYSOKOŠKOLSKÝ UČITEL, PŘEKLADATEL
}

Na katedře překladatelství a tlumočnictví, později translatologie, jsem studoval angličtinu a ruštinu v letech 1980-1985, tedy v době tuhé normalizace, kdy se o událostech listopadu 1989 nikomu nemohlo ani zdát. Studoval jsem večerně, jinak to pro mě už vůbec nepřipadalo v úvahu, celých pět let jsem při studiích pracoval jako noční hlídač, což ovšem bylo velice výhodné.

Pohyboval jsem se tehdy ve dvou „paralelních světech“: jednak ve společenství chartistického disentu a tehdy notně prořídlého, zdecimovaného kulturního undergroundu (představitelé mladší undergroundové generace zejména z okruhu Revolver Revue tehdy byli na samém počátku svých uměleckých cest, byli ještě zcela neznámí, většina osobností staršího undergroundu byla bud' v nuceném exilu, nebo ve vězení, někteří se stáhli do „exilu vnitřního“, tedy do ústraní, byla to vskutku beznadějná léta), jednak mezi studenty na Filosofické fakultě UK, kteří ovšem nemohli, nesměli mít nejmenší tušení, že také ve volných chvílích opisuji samizdaty, účastním se různých bytových seminářu a sem tam jezdím i na různé undergroundové koncerty.

Světa tehdejších studentů a ovšem zejména vysokoškolských pedagogů jsem se obával, měl jsem k němu nedůvěru jako ke všemu oficiálnímu, co podléhalo kolaboraci v rámci husákovského režimu, který jsem nenáviděl. Na FF UK jsem se v roce 1980 dostal snad nedopatřením, snad zázrakem, snad proto, že se některému z tehdejších partajních či vnitráckých mocipánů zachtělo učinit velkorysé gesto. Nevěděl jsem tehdy, čemu za to vděčím, nevím to dodnes, ale těch pět let na FF jsem byl ve stálých obavách, že kdykoli by se zachtělo těm, kdo tehdy svévolně rozhodovali o osudu lidí v této zemi, mě ze dne na den pod jakoukoli záminkou zase ze studií vyhodí.

Ale studovat jsem chtěl - cizí jazyky, literaturu, dějiny literatury -, byt’ jsem počítal s tím, že co na tehdejší univerzitě získám, budu si muset doplňovat $\mathrm{z}$ jiných zdrojů.

Na FF UK jsem tedy na podzim 1980 začínal studovat postižen takto černobílým vnímáním světa - a ovšem s apriorní nedůvěrou ke všem představitelům tehdejší akademické obce. Neuvědomoval jsem si zejména jednu věc, totiž že stejně jako já se obávám tehdejších pedagogů, kteří mi splývali v jednu šedou normalizační masu, též někteří z nich se mohou bát nejen svých nadřízených, ale i kolegů, ba i studentů. Strach a vzájemná nedůvěra tehdy ovládaly vše, bylo neustále třeba mít se na pozoru...

Ani o Jarmile Emmerové jsem tehdy nevěděl nic, byt - ale to jsem si uvědomil až později - jsem některé její překlady z angličtiny už četl, třeba Hardyho či Bradburyho. Nic jsem nevěděl o její práci v Odeonu v 60. letech, o jejích kontaktech s Janem Zábranou 
či s Josefem Škvoreckým, nic o tom, že dříve působila na katedře anglistiky, odkud byla naštěstí jen „přesunuta“ na katedru PT, ne nadobro vyhozena.

Poprvé jsme se s Jarmilou Emmerovou my, tehdejší studenti prvního ročníku, setkali u příležitosti jakéhosi testu, jenž byl součástí přijímacích zkoušek. Myslím, že šlo o diktát. Do učebny vstoupila velmi elegantní usměvavá blondýna středního věku, oči skryté za silnými brýlemi. Promluvila k nám nejprve pár slov velmi kultivovanou a přitom nikterak pedagogicky strojenou češtinou, vysvětlila, oč půjde. Pak rozlepila obálku, vzala anglický text a začala diktovat. Pamatuji si dobře, že text se jmenoval „Puma at large“, tedy „Puma v př́rodě“ či „volně pobíhající puma“, foneticky přepsáno [pju:mə æt la:dž]. Idiom „at large“ jsem tehdy neznal, co je [pju:mə] jsem jaksi z kontextu vytušil; jak jsem to tehdy napsal, to jsem se nikdy nedozvěděl, ale anglická výslovnost paní doktorky mě již tehdy rázem okouzlila. To BYLA angličtina! Bylo okamžitě zřejmé, že tato pedagožka angličtinu prožívá, že ji miluje, že ji skvěle zná. A již tehdy se mé předsudky o beznadějné šedivé průměrnosti normalizačních vysokoškolských učitelů trochu narušily: byl tu paprsek světla v temnotách, trocha naděje. Mít takovouto vyučující by bylo skvělé.

Dnes je obtížně vysvětlitelné, jak v atmosfére strachu, kdy nelze veřejně říkat, co si myslím, začnou fungovat jiné způsoby dorozumívání. Zažíval jsem to ostatně už od poloviny 70 . let $\mathrm{v}$ undergroundovém společenství: to byla radost, pocit sounáležitosti, potěcha z toho, že se něco dobrého daří, navzdory omezováním a zákazům: o nějaké politice nepadlo ani slovo, měli jsme svůj krásný, vyvzdorovaný svět.

A vlastně totéž, tentýž pocit vyvzdorované komplicity, jsem pak zažil na FF s několika málo učiteli, především s Jarmilou Emmerovou.

Paní doktorka, jak jsme jí tehdy samozřejmě všichni říkali, nás dokázala strhnout svým entusiasmem, svým zaujetím pro věc, pro poctivou práci, která nemůže nebýt náročná, pro krásu jazyka, pro bohatství literatury, která, je-li studována poctivě, vždy otevírá svobodný myšlenkový a estetický prostor, jejž nemůže žádný totalitní režim zničit ani přehlušit. Ano, nejlepší česká literatura byla tehdy zatlačena do podzemí, do samizdatu, př́ípadně do exilu, ale zahraniční literární scény, ovšem především ty velké západní, si tehdejší přeostražitá československá cenzura nemohla podmanit.

Když Jaroslav Hutka v 70. letech zpíval „Žalm 12“ („celý den lháti, to na práci mají / falešnou řečí živí bližního..."), nebylo třeba nic vysvětlovat a dodávat. Když jsme jako studenti pak četli Shakespearovy sonety třeba v Saudkově překladu, ovšem také často citovaný sonet šestašedesátý ( „... a umění jak panáčkuje vládě / a doktor Blbec káže géniům / a lumpové se posmívají pravdě / a Dobro babě Zlu jak smejčí dům..."), bylo to stejně naléhavé, ale tehdy jsme si již uvědomovali, že literatura nejsou jen subverzivní jinotaje, že jde o celé svobodné univerzum, jehož se však nelze zmocnit jinak než poctivým studiem, náročnou prací. A právě v tom nám byla skvělým př́ikladem Jarmila Emmerová. Vlastně už to samo bylo cosi „protirežimního“: vždyt československá normalizace byla založena na oné „tiché dohodě“, na onom tolik demoralizujícím konsensu mezi kryptokonzumenty, oněmi „malými českými lidmi“, jejichž heslem bylo, „kdo nekrade, okrádá rodinu“, tedy nepoctivost, a husákovským režimem, jemuž svými hlasy tito lidé dodávali zdání legality. Poctivě pracovat, poctivě něco studovat? Jaký to byl tehdy anachronismus, jaká absurdnost. Měl jsem pocit, že něco takového je možno jen v onom světě disentu a undergroundu, ale najednou jsem si uvědomil, že to je možno i jinde. 
Žádná velká slova nebyla zapotřebí, žádné pokoutní dorozumívání o tom, že jsme „proti“. Již jen samotným studiem literatury, umění, světa myšlenek se přirozeně dospívá k názorovým střetům, k zjištění, že někdo někde chce svobodný tok informací a idejí omezit, zastavit. A zjistíme-li něco takového, pak - jde-li nám opravdu o věc, a nejen o kariéru - nelze než být proti těmto omezením a zákazům, proti těm, kdo tyto zákazy vydávají. To je posléze něčím zcela samozřejmým.

Jarmila Emmerová během let mých studií vedla na PT různé překladatelské semináře, v nichž jsme se také učili, že o dobrý, funkčně adekvátní překlad je možno se pokusit nejen s patřičnou znalostí jazyka, z něhož se překládá (a ovšem s trvalým vědomím toho, že vlastně jsme stále „na začátku“, že si nikdy nesmíme říci, že toho víme dost, že jde o celoživotní úsilí, kdy je stále co zlepšovat, co se učit), ale stejně tak jazyka mateřského, o jehož kultivovanou úroveň je nutno svádět zápas stejně náročný a stejně neustálý. Snad se zde sluší připomenout, že v „normalizačních“ letech byly takovéto snahy vlastně stejně anachronicky „subverzivni“ jako výše zmíněné jinotaje; vždyt’ v ústech tehdejších partajníků zněl jejich rodný jazyk přečasto jako podivná úřední hatmatilka, jako jakési „ptydepe“ či „českoslovenština“, které zesměšňovali Václav Havel či Josef Škvorecký. A ostatně, za ta desetiletí se v tomto ohledu u nás tak mnoho nezměnilo, bojovat je stále s čím, žel, dnes už víme, že jde o boj s hydrou.

Jarmile Emmerové tedy v tomto ohledu vděčím opravdu za mnoho. A nepochybuji, že se to týká desítek, stovek, možná tisíců dalších jejích studentů již několika generací. A ovšem také čtenářủ jejích vynikajících překladů, které by opět mohly být prríkladem práce vskutku náročné, přepečlivé.

Během pěti let svých studií na FF jsem se navzdory „době“ setkal s řadou pedagogů, kterých jsem si mohl vážit a jejichž práce mi byla př́kladem. Z rusistů mi byli na PT v tomto ohledu vzorem překladatel Ladislav Zadražil, nadšená propagátorka díla Mariny Cvetajevové Galina Vaněčková či literární historička Marta Čížková, kteří se všichni ve skutečnosti na FF drželi jen tak tak, což jsem se ovšem dozvěděl mnohem později, vlastně až po roce 1989. Z anglistů to byl jistěže profesor Hilský, který však na PT neučil, svými znalostmi mi velmi imponoval lexikograf profesor Poldauf, bohužel na začátku 80. let již dosti nemocný, vážil jsem si překladatelky a literární historičky Evy Masnerové, která se v časově značně limitovaných přednáškách snažila dodat nám maximum z přehledu dějin angloamerické literární scény. Jarmilu Emmerovou jsme ale milovali a milujeme ji dodnes. Jarmila Emmerová mi byla a je nejlepším příkladem univerzitního pedagoga, u něhož dobré znalosti daného oboru jsou samozřejmostí; jde však také o to, jak své znalosti dokáže pedagog předat dále, zaujmout jimi posluchače. A to nejde bez osobního zaujetí, bez entusiasmu, bez bytostné víry, že dobrá práce uspěje navzdory těm či oněm „poměrům“. To Jarmila Emmerová dokázala, a proto mně osobně byla vždy také příkladem mravním.

Jsem štasten, že jsem mohl na svých studiích mít Jarmilu Emmerovou za jednoho ze svých učitelů. 